\title{
RESPONSE OF SQUASH TO DEFICIT IRRIGATION AND POTASSIUM FERTILIZATION UNDER SOLAR - POWERED DRIP IRRIGATION
}

\author{
Elmetwalli, A.H.*
}

\section{ABSTRACT}

The availability of fresh water and energy resources in remote locations is a major challenge for agricultural crop production in many countries in the Middle East region. Using limited water resources efficiently is crucial to sustain rapidly population growth. This research aimed to investigate the possibility of enhancing productivity and water productivity of squash crop through deficit irrigation technique. Two field studies were carried out to investigate the response of squash crop to deficit irrigation (DI) technique and potassium fertilization $(K)$ over the spring and fall seasons of 2018. The irrigation treatments were based on the reference evapotranspiration (ETo). The results showed that the optimum squash seed yield could be obtained with K fertilizer level of 250 $\mathrm{kg} \mathrm{K}_{2} \mathrm{O} \mathrm{ha} \mathrm{h}^{-1}$ and irrigation with amount of water equals $75 \%$ of ETo using DI with laterals placed at $0.15 \mathrm{~m}$ from crop row or $50 \%$ of ETo in the last stage using RDI techniques. Fully irrigated (1.0 ETo) treatments had the highest values of yield and yield components of squash and there were no significant differences with RDI and DI with 0.75 ETo. The application of RDI can save more than $20 \%$ of applied water with no significant reductions in squash yield. Potassium rates enhanced squash yield and water productivity with the greatest value at $250 \mathrm{~kg} \mathrm{~K}_{2} \mathrm{O}_{5} \mathrm{ha}^{-1}$.

Key words: squash, deficit irrigation, applied, water, solar, pumping, potassium fertilization.

\section{INTRODUCTION}

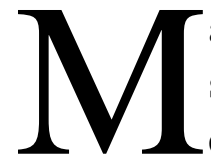
any regions of the world suffer shortage of traditional energy sources in remote locations while having abundant renewable energy sources (solar and wind energy) particularly in African countries. Solar power offer huge opportunities to improve the energy access in many areas of the developing worldwide by providing a huge source of clean and cost-effective source of energy.

*Assoc.Prof of Agric.Eng.,Agric.Eng.Dept., Faculty of Agric.,Tanta Univ. 
Solar - powered pumping systems are likely to be a promising alternative for irrigating agricultural crops in the remote locations. In Egypt more than $95 \%$ of cultivated landmass is under irrigation and most of the newly reclaimed areas have no grid connection and subsequently solar powered pumps can be a reliable way to enhance crop production in these locations. Previous studies documented the effectiveness of PV pumping systems for irrigating agricultural crops (Burney et al., 2010 and AbuAligah, 2011). It is therefore obvious that solar energy captured by PV solar cells can be a robust way to operate drip irrigation systems since they are comparable and cost effective to diesel powered pumps (Odeh et al., 2010). Hossain et al., (2015) reported that solar powered pump systems are profitable more than diesel powered pumps.

One of the main challenges facing humanity is how to use limited and scarce natural resources in a sustainable way. According to Seckler, (1999) scarcity of water is now the single greatest threat to the global food supply. Widespread, agriculture is the main consumer of water. More than $85 \%$ of the allocated water budget to Egypt is used for irrigation purposes and thus water availability has a direct impact on national food security. Therefore, the proper irrigation management and scheduling has become a determinant factor in crop production in these regions (Kang and Zhang, 2004). Moreover, worldwide water scarcity and predicted climate change have demanded emphasis on utilizing available water resources more efficiently via assessing critical plant water status factors for accurate and reliable irrigation water management (Anderson et al., 2008).

Introducing new irrigation techniques (i.e. PRD and RDI) that are suitable and successful to conserve the scare irrigation water resources would be important. These techniques can be reliable to reduce the demand for water at the farm level, and control the negative effects of over-irrigation (Pereira et al. 2002).

This challenge has promoted research into irrigation systems techniques and strategies to enhance yield productivity and thus water use efficiency (WUE). PRD is among water saving techniques in which half of the root system is exposing to alternate drying and wetting cycles. Basically, well watered side of the soil maintains a well plant status while dehydration of 
the other side encourages the synthesis of the abscisic acid and therefore decrease stomata conductance (Giuliani et al., 2017). Among various irrigation techniques PRD has the potential of increasing water use efficiency and sustain yield of different crops (Hu et al., 2009; Nardella et al., 2012; Yactayo et al., 2013; Marjanovic et al., 2015; Wei et al. 2016 and Gomaa et al., 2018 Qi et al., 2019).

DI irrigation has been shown as an effective irrigation strategy to save water while maintaining yield reductions at the minimum and increase WUE (Nangare et al., 2016 and Mele 2019). RDI is among the most reliable irrigation techniques which designed to save water while having little negative effect on yield (Naor, 2006). This technique can be achieved by applying deficit irrigation at certain growth stage when the crop is relatively tolerant to moisture stress (non critical times). RDI was used successfully in reducing irrigation rate while having similar yields (Romero et al., 2004). Generally, the main aim of RDI is to increase WUE via either decreasing the amount of irrigation water of the number of irrigations (Kirda, 2002).

Attention should also be considered to potassium fertilization (K) when cultivating vegetable crops since it is the most absorbed micronutrients by most of these crops (Fernandes et al., 2016). Fertilization plays an important role in the absorption of macronutrients in various plant organs and formation of the yield. Haytova (2013) concluded that squash is a vegetable crop responsive to fertilization as a result of rapid accumulation of vegetative mass in a relatively short period of time. The overall aim of this research was to assess the potential of RDI and potassium fertilization on enhancing yield and water productivity of squash crop under solarpowered drip irrigation system.

\section{MATERIALS AND METHODS}

\section{Experimental Site and Design}

Field experiments were conducted at a private farm in Nubaria region $\left(30^{\circ} 4^{\prime} 12^{\prime \prime} \mathrm{N}\right.$ and $\left.30^{\circ} 19^{\prime} 48^{\prime \prime} \mathrm{E}\right)$ during the spring and fall seasons of 2018. Disturbed and non-disturbed soil samples were collected at two depths of the soil profile $(0-30$, and $30-60 \mathrm{~cm})$ to determine some main physical and chemical characteristics. The experimental soil was classified as loamy sand in texture, with an EC of $1.32 \mathrm{dS} \mathrm{m}^{-1}$. Table (1) 
shows the details of the chemical analysis of the experimental soil. Squash was sown during the first week of March and last week of July and the growing season lasted to around 105 days after planting. The hydro physical properties of the experimental soil were also determined including field capacity, welting point and available water (Table 2). Nitrogen fertilization in the form of ammonium nitrate was added with the recommended rate $\left(285 \mathrm{~kg} \mathrm{~N} \mathrm{ha}^{-1}\right)$ in three equal doses at 30,45 and 60 days after planting.

Table (1): Some chemical analysis of the experimental soil at different soil depths

\begin{tabular}{|c|c|c|c|c|c|c|c|c|c|c|}
\hline \multirow{2}{*}{$\begin{array}{c}\text { Soil } \\
\text { depth, } \\
\mathrm{cm}\end{array}$} & \multirow{2}{*}{$\begin{array}{c}\mathrm{EC}, \\
\mathrm{dS} / \mathrm{m}^{-}\end{array}$} & \multirow{2}{*}{$\mathrm{pH}$} & \multicolumn{4}{|c|}{ Cations, meq/L } & \multicolumn{4}{c|}{ Anions, meq/L } \\
\cline { 4 - 11 } & $\mathrm{Mg}^{++}$ & $\mathrm{Ca}^{++}$ & $\mathrm{K}^{+}$ & $\mathrm{Na}^{+}$ & $\mathrm{Co}_{3}^{--}$ & $\mathrm{HCo}_{3}^{--}$ & $\mathrm{Cl}^{-}$ & $\mathrm{So}_{4}^{--}$ \\
\hline $0-30$ & 1.32 & 7.39 & 3.2 & 3.21 & 1.28 & 4.77 & 0.0 & 2.71 & 7.18 & 2.54 \\
\hline $30-60$ & 1.17 & 7.21 & 3.33 & 3.34 & 1.37 & 4.61 & 0.0 & 2.77 & 7.36 & 2.51 \\
\hline
\end{tabular}

Table (2): Mechanical analysis and some soil physical properties

\begin{tabular}{|c|c|c|c|c|c|c|c|c|}
\hline \multirow{2}{*}{$\begin{array}{c}\text { Depth, } \\
\mathrm{cm}\end{array}$} & $\rho_{\mathrm{b}}$, & $\mathrm{FC}$, & $\mathrm{WP}$, & $\mathrm{AW}$, & \multicolumn{2}{|c|}{ Particle size } & \multirow{2}{*}{ Texture } \\
\cline { 5 - 8 } & $\mathrm{gcm}^{-3}$ & $\%$ & $\%$ & $\%$ & Sand & Silt & clay & \\
\hline $0-30$ & 1.40 & 16.9 & 9.34 & 7.56 & 87.3 & 6.36 & 6.34 & Loamy sand \\
\hline $30-60$ & 1.56 & 15.13 & 8.35 & 6.78 & 86.3 & 7.52 & 6.18 & Loamy sand \\
\hline
\end{tabular}

FC, field capacity; WP, wilting point; AW, available water; $\boldsymbol{\rho}_{\mathbf{b}}$, bulk density

\section{Solar - powered pumping and irrigation systems}

The solar - powered pumping system consisted of 40 solar modules (JKM 250P-60) comprised of two groups 20 modules each connected in series then both groups connected together parallelly (Fig 1). Each solar cell had the dimensions of $165 \mathrm{~cm}$ length, $99.2 \mathrm{~cm}$ width and $4 \mathrm{~cm}$ thickness. Both solar cell groups were oriented facing south direction. The 40 PV cells $(250 \mathrm{~W})$ produced enough energy to operate the pump that was able to supply the required amount of water for the whole farm. This solar 
powered pumping system was designed to irrigate a 20 feddan farm comprising citrus and vegetable crops. The solar irradiance varied from month to another with the maximum and the minimum of 7.1 and $3.8 \mathrm{kWh} \mathrm{m}^{-2}$ recorded in June and December, respectively. A $10 \mathrm{~kW}$ maximum power controller (PS9K2) was linked to the solar modules with an efficiency of $98 \%$. A $7.5 \mathrm{~kW}$ PUC-SJ30-7 submersible pump was used to deliver water to drip irrigation network. The solar system worked from sunrise to sunset producing the maximum discharge rate at noon.

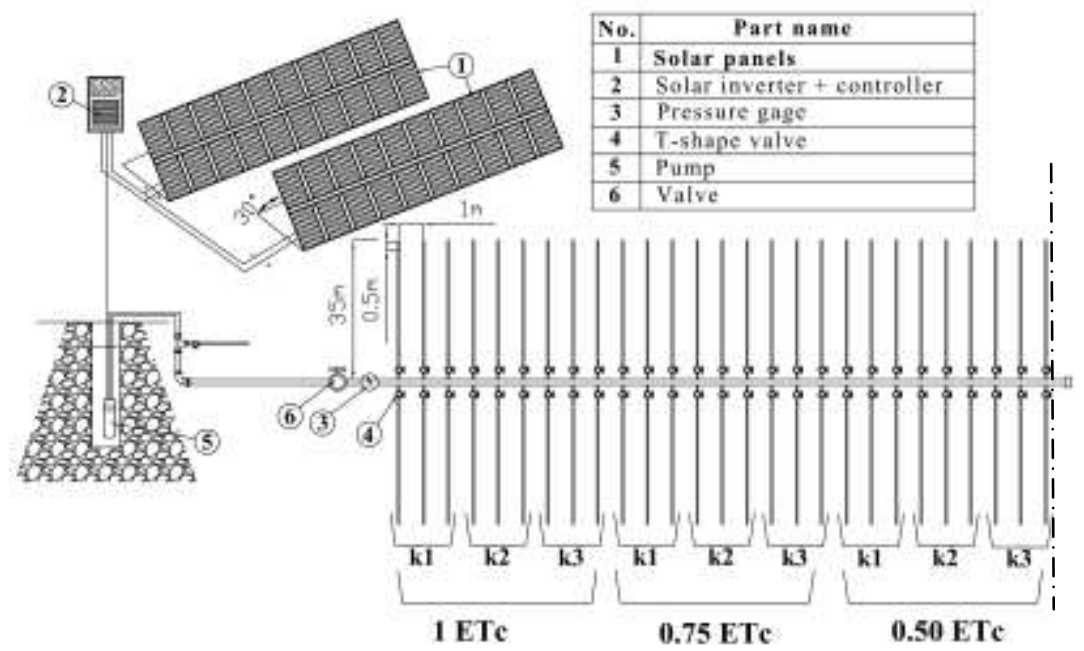

Fig. (1): A schematic diagram showing the solar - powered system connected with the drip irrigation network; ETc -crop water requirements and $\mathrm{k}_{1}, \mathrm{k}_{2}, \mathrm{k}_{3}$ - potassium fertilization rates

A drip irrigation network was employed for irrigating the experimental plots. $16 \mathrm{~mm}$ polyethylene lateral lines were spaced at $1.0 \mathrm{~m}$ with dripper of $4 \mathrm{~L} \mathrm{~h}^{-1}$ discharge rate spaced at $0.5 \mathrm{~m}$. A pressure differential tank was used for the application of fertilizers. A split-plot experimental design with three replicates was used with an experimental unit consisting of nine 35- $\mathrm{m}$ long lateral lines with built-in emitters of $4 \mathrm{~L} \mathrm{~h}^{-1}$ discharge rate. Irrigation treatments were randomly assigned to the main plots and $\mathrm{K}$ rates were assigned to the sub-mains. The amount of irrigation water was based on ETo that was determined using Class A pan evaporation data. The experimental design included 6 irrigation combinations $\left(1 \mathrm{ET}_{\mathrm{o}}\right.$, $0.75 \mathrm{ET}_{\mathrm{o}}, 0.50 \mathrm{ET}_{\mathrm{o}}, \mathrm{DI}_{3}-0.75 \mathrm{ETo}$ and laterals spaced at $0.15 \mathrm{~m}$ from 
crop row, $\mathrm{DI}_{4}-0.50$ ETo and laterals spaced at $0.15 \mathrm{~m}$ from crop row and RDI) and three doses of $\mathrm{K}\left(150,200\right.$ and $\left.250 \mathrm{~kg} \mathrm{~K}_{2} \mathrm{O}_{5} \mathrm{ha}^{-1}\right)$. RDI: $100 \%$ ETo throughout the growing season, and only 50\% ETo at the seeding and maturation growth stage (regulated deficit irrigation). Potassium fertilization was applied ten times (weekly) starting from two weeks after planting and the applied amount of $\mathrm{K}$ was differed according to each treatment. The irrigation techniques were as follows:

To ensure high germination ratio all treatments were fully irrigated for 21 days and then various treatments were applied.

\section{Applied Irrigation Water:}

Reference evapotranspiration ( $\mathrm{ET}_{\mathrm{o}}$ ) based on the Class A pan evaporation method (Doorenbos and Kassam, 1986) was identified according to the following equation:

$$
\text { ETo }=\text { Epan } \times \text { Kpan }
$$

Where: ETo- reference evapotranspiration $\left(\mathrm{mm} \mathrm{d}^{-1}\right)$, Epan-daily measured pan evaporation $\left(\mathrm{mm} \mathrm{d}^{-1}\right)$, Kpan-pan coefficient. 0.75 was taken for the experimental site according to the local climatic condition (FAO, 1970). The amount of applied water was calculated according to Vermeiren and Jopling (1984) as follows:

$$
A I W=\frac{E T o \cdot K r . I}{E a}
$$

where: AIW - the depth of applied water, mm; ETo - reference evapotranspiration, $\mathrm{mm} \mathrm{day}^{-1} ; \mathrm{K}_{\mathrm{r}}$ is the reduction factor that depends on ground cover and according to James (1988), it was assumed to be 1.0 since the spacing between drip lines was less than $1.8 \mathrm{~m} ; \mathrm{E}_{\mathrm{a}}$ is the drip irrigation system efficiency which was assumed to be on average 0.8 and I - irrigation interval, days.

Irrigation time was identified before an irrigation event according to Ismail (2002) as follows:

$$
T=\left(\frac{A I W \times A}{q}\right)
$$

Where: $\mathrm{T}$ - irrigation time, $\mathrm{h} ; \mathrm{A}-$ the wetted area by each emitter, $\mathrm{m}^{2}$ and $\mathrm{q}$ - emitter discharge rate, $\mathrm{L} \mathrm{h}^{-1}$ 


\section{Water Use Efficiency}

Water use efficiency ( $\mathrm{kg}$ of squash seeds per $\mathrm{m}^{3}$ of water applied) was calculated as follows:

$$
W U E=\frac{\text { squash seed yield }\left(\mathrm{kg} \mathrm{ha}^{-1}\right)}{\text { applied irrigation water }\left(\mathrm{m}^{3} \mathrm{ha}^{-1}\right)}
$$

\section{Potassium Use Efficiency (KUE)}

Potassium use efficiency was calculated as follows:

$$
K U E=\frac{Y}{K}
$$

Where: KUE is the potassium use efficiency, $\mathrm{kg}$ of squash seeds $(\mathrm{kg}$ $\left.\mathrm{K}_{2} \mathrm{O}_{5}\right)^{-1}$

$\mathrm{Y}$ is the squash yield in $\mathrm{kg} \mathrm{ha}^{-1}$ in a certain treatment; $\mathrm{K}$ is the added amount of $\mathrm{K}_{2} \mathrm{O}_{5}$ to the same treatment

\section{Statistical Analysis:}

SAS software package was run to subject experimental data to statistical analysis. Least significant difference (LSD) at 5\% significance level was used to compare the means of various treatments.

\section{RESULTS AND DISCUSSION}

\section{Solar - powered irrigation pumping system productivity}

The energy produced from the pumping system ranged from a minimum of $33 \mathrm{kWh}$ in December to a maximum of $56 \mathrm{kWh}$ in the period of June and July (Fig. 2). From May to August, the system produced roughly the same amount of energy. The average daily produced energy over the whole year was $48 \mathrm{kWh}$. The experimental site is sunny most of the year with a few cloudy days during the winter months (December to February). The water discharge rate of the system varied throughout the year based on the energy produced every month since the energy is a function of sunlight hours. The greatest daily water discharge rate of 279 $\mathrm{m}^{3}$ day ${ }^{-1}$ was recorded in June followed by July $\left(274 \mathrm{~m}^{3}\right.$ day $\left.{ }^{-1}\right)$ and the minimum record of discharge rate was recorded in December $\left(158 \mathrm{~m}^{3}\right.$ 
day $\left.^{-1}\right)$. From May to August, similar trend like produced energy the solar powered pumping system produced was roughly the same as the water discharge rate (less than $5 \%$ increase). Fig. 3 illustrates the average daily water discharge rate in different months throughout the year. The system was designed to convey water directly to the drip irrigation network or to the water reservoir to use it over night when the solar system stops working.

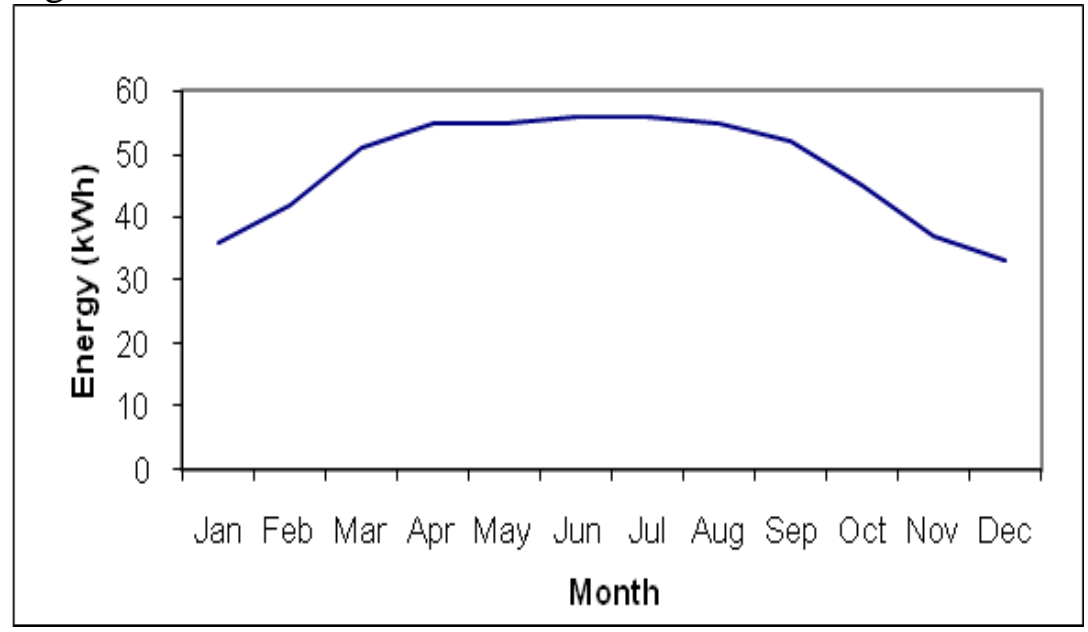

Fig. (2): Average daily energy $(\mathrm{kWh})$ produced by the solar - powered pumping system used througout the year

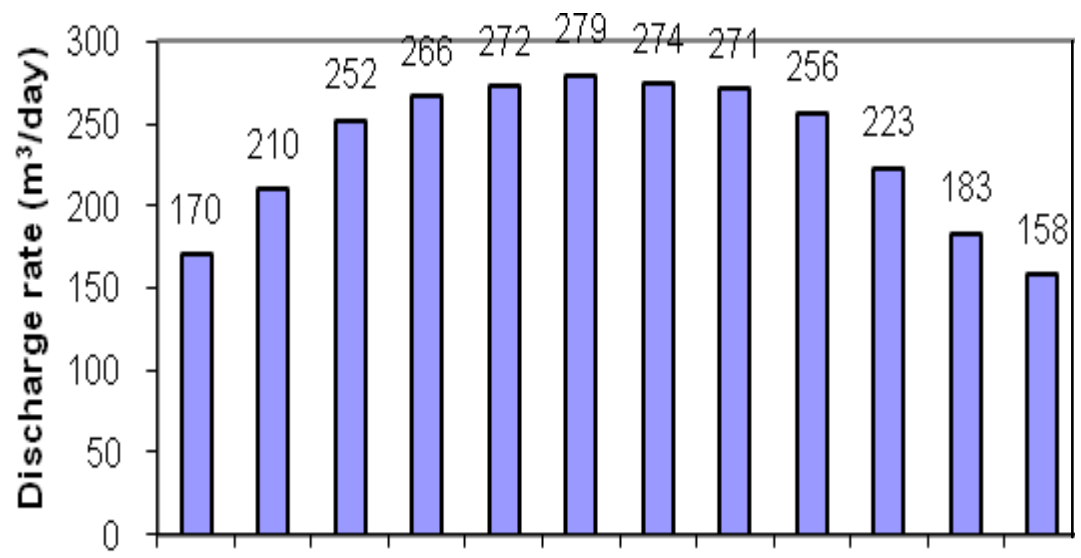

Jan Feb Mar Apr May Jun Jul Aug Sep Oct Nov Dec

Month

Fig. (3): Average daily discharge rate $\left(\mathrm{m}^{3} \mathrm{day}^{-1}\right)$ of the solar - powered pumping system used over the year 


\section{Effects of irrigation treatments and potassium fertilization on squash seed yield}

The results detailed in Table 3 demonstrate the effect of irrigation techniques and potassium fertilization on squash seed yield. There were significant effects of investigated parameters on squash seed yield in both spring and fall growing seasons. No significant reductions were observed between fully irrigated treatments and those irrigated by $\mathrm{DI}_{3}$ and RDI since the reductions were 8.9 and $10.4 \%$ in spring season and 9.4 and $6.5 \%$ in fall season, respectively. The results further demonstrated that applying $\mathrm{DI}_{4}$ with $50 \%$ ETc produced 19.8 and $23.5 \%$ higher yield compared with $\mathrm{DI}_{1}(50 \% \mathrm{ETc}$ normal) in spring and fall seasons, respectively. In this context, applying mild stress via RDI and DI can save water by at least $20 \%$ without significant reductions in squash seed yield and this is crucial in cases of water scarcity in arid and semi arid regions. Data also showed that increasing applied K rate remarkably increased the yield of squash. The maximum squash yield values of 1110.2 and 1077.2 $\mathrm{kg} \mathrm{ha}^{-1}$ were obtained from the treatments served by the combination 1.0 ETc and $250 \mathrm{~kg} \mathrm{~K}_{2} \mathrm{O}_{5} \mathrm{ha}^{-1}$ in spring and fall seasons respectively. For a given irrigation technique, squash seed yield showed significant difference among $\mathrm{K}_{2} \mathrm{O}_{5}$ fertilization rates. Great rates of $\mathrm{K}_{2} \mathrm{O}_{5}$ may reduce the water stress effect due to the dominant role of $\mathrm{K}$ in controlling stomata opening, which regulates the transpiration of water. Low squash yields obtained from the smallest dose of $\mathrm{K}$ showed its vital necessity for photosynthesis since in case of $\mathrm{K}$ deficiency reductions in photosynthesis rate occurs and so decreasing the accumulation of carbohydrates. Another effect of the lack of $\mathrm{K}$ for plants is that the stomata do not open regularly that result in reduced carbon dioxide and subsequently lower photosynthesis intensity and ending up with lesser yield.

From the above mentioned results it can be concluded that choosing the proper $\mathrm{K}$ rate coupled with the RDI and DI irrigation techniques for growing squash crop can result in saving at least $20 \%$ of the applied irrigation water required for full irrigation due to reduced root size distribution. The results obtained in this research regarding the AIW are similar to those reported by Topcu et al. (2007). 
Table (3): Effect of irrigation treatment and $\mathrm{K}$ rates on squash seed yield $\left(\mathrm{kg} \mathrm{ha}^{-1}\right)$ in both investigated seasons

\begin{tabular}{|c|c|c|c|c|c|}
\hline \multirow{2}{*}{ Season } & \multirow{2}{*}{$\begin{array}{l}\text { Irrigation } \\
\text { treatment }\end{array}$} & \multicolumn{3}{|c|}{ K Fertilization, $\mathrm{kg} \mathrm{ha}^{-1}$} & \multirow{2}{*}{ Mean } \\
\hline & & 150 & 200 & 250 & \\
\hline \multirow{6}{*}{$\begin{array}{l}\text { Spring } \\
2018\end{array}$} & $1.0 \mathrm{ETc}$ & 812.3 & 989.3 & 1110.2 & 970.6 a \\
\hline & $0.75 \mathrm{ETc}$ & 466.5 & 756.7 & 968.6 & $730.6 \mathrm{c}$ \\
\hline & $0.50 \mathrm{ETc}$ & 522.1 & 558.4 & 778.4 & $619.6 \mathrm{~d}$ \\
\hline & RDI & 712.4 & 908.3 & 986.3 & $869.0 \mathrm{ab}$ \\
\hline & $\mathrm{DI}_{3}$ & 685.4 & 880.6 & 1089.2 & $885.1 \mathrm{ab}$ \\
\hline & $\mathrm{DI}_{4}$ & 588.8 & 756.7 & 972.6 & $772.7 \mathrm{bc}$ \\
\hline Mean & & 631.3 & 808.3 & 984.2 & \\
\hline \multirow{6}{*}{ Fall 2018} & $1.0 \mathrm{ETc}$ & 810.7 & 968.9 & 1077.2 & $952.3 \mathrm{a}$ \\
\hline & $0.75 \mathrm{ETc}$ & 466.1 & 502.1 & 952.0 & $640.1 \mathrm{bc}$ \\
\hline & 0.50 ETc & 515.5 & 530.8 & 605.1 & $550.4 \mathrm{c}$ \\
\hline & RDI & 813.3 & 891.6 & 965.3 & $890.1 \mathrm{a}$ \\
\hline & $\mathrm{DI}_{3}$ & 731.0 & 818.7 & 1036.9 & $862.2 \mathrm{a}$ \\
\hline & $\mathrm{DI}_{4}$ & 516.5 & 790.4 & 854.0 & $720.3 \mathrm{~b}$ \\
\hline Mean & & 642.2 & 750.4 & 915.1 & \\
\hline
\end{tabular}

\section{Applied Irrigation Water:}

Table 4 details the amounts of applied water to various irrigation techniques in both investigated seasons of squash crop over different growth stages. The results revealed that the amount of applied water was less over the vegetative growth period in spring and fall seasons and reached its peak during fruits formation stage and then decreased again over seeding and maturation growth stage. The highest amounts of applied water were associated with the fruits formation and flowering growth stages recording 134.66, 102.5 and 111.43, $89.96 \mathrm{~mm}$ for spring and fall seasons, respectively. Same amounts of applied water were added to all treatments for the $1^{\text {st }}$ growth stage (vegetative stage) to ensure high percentage of germination. The application of $\mathrm{DI}_{3}$ treatment saved water by $21 \%$ with little yield reductions compared with fully irrigated treatments. It is therefore obvious that the RDI and DI irrigation would be 
efficient systems to apply less water to tolerant crops while having similar grain yields.

Table (4): Applied irrigation water (AIW) in $\mathrm{mm}$ for squash at various growth stages with different irrigation treatments in spring and fall seasons

\begin{tabular}{cccccccc}
\hline \multirow{2}{*}{ Season } & Growth & \multicolumn{7}{c}{ Irrigation treatments and regimes } \\
& stage & $1.0 \mathrm{ETc}$ & 0.75 & $0.5 \mathrm{ETc}$ & $\mathrm{RDI}$ & $\mathrm{DI}_{3}$ & $\mathrm{DI}_{4}$ \\
& & & $\mathrm{ETc}$ & & & & \\
\hline \multirow{3}{*}{ Spring } & Vegetative & 53.9 & 53.9 & 53.9 & 53.9 & 53.9 & 53.9 \\
2018 & Flowering & 102.5 & 76.78 & 51.25 & 102.5 & 76.87 & 51.25 \\
& Fruits & 134.66 & 100.99 & 67.33 & 134.66 & 100.99 & 67.33 \\
& Seeding & 78.75 & 59.06 & 39.38 & 39.38 & 59.06 & 39.38 \\
\cline { 2 - 8 } & Total & $\mathbf{3 6 9 . 8 1}$ & $\mathbf{2 9 0 . 8 2}$ & $\mathbf{2 1 1 . 8 6}$ & $\mathbf{3 3 0 . 4 4}$ & $\mathbf{2 9 0 . 8 2}$ & $\mathbf{2 1 1 . 8 6}$ \\
\hline \multirow{3}{*}{ Fall 2018} & Vegetative & 45.98 & 45.98 & 45.98 & 45.98 & 45.98 & 45.98 \\
& Flowering & 89.96 & 67.47 & 44.98 & 89.96 & 67.47 & 44.98 \\
& Fruits & 111.43 & 83.57 & 55.72 & 111.43 & 83.57 & 55.72 \\
& Seeding & 61.72 & 46.29 & 30.86 & 30.86 & 46.29 & 30.86 \\
\cline { 2 - 8 } & Total & $\mathbf{3 0 9 . 0 9}$ & $\mathbf{2 4 3 . 3 1}$ & $\mathbf{1 7 7 . 5 4}$ & $\mathbf{2 7 8 . 2 3}$ & $\mathbf{2 4 3 . 3 1}$ & $\mathbf{1 7 7 . 5 4}$ \\
\hline
\end{tabular}

\section{Water Use Efficiency of squash (WUE)}

The effects of irrigation management and K-fertilization rate on water use efficiency (WUE) for both tested seasons are detailed in Table 5. The results demonstrated that WUE values were higher in the treatments that received the combination of $\mathrm{DI}_{3}$ and $\mathrm{DI}_{4}$ with the highest rate of $\mathrm{K}$ fertilization. It is obvious that applying less water to squash with deficit irrigation with laterals placed at $0.15 \mathrm{~m}$ produced higher seed yield in comparison to normal deficit treatments having the same amount of applied water. The greatest WUE records were obtained with $\mathrm{DI}_{3}$ and $\mathrm{DI}_{4}$ in all treatments at all rates of potassium fertilization rates. RDI technique produced more or less the same seed yield like fully irrigated treatments while saving at least $20 \%$ of water applied in both spring and fall growing seasons. The greatest WUE of 0.459 and $0.481 \mathrm{~kg} \mathrm{ha}^{-1}$ were obtained from the combination of $\mathrm{DI}_{4}$ and $250 \mathrm{~kg} \mathrm{~K}_{2} \mathrm{O}_{5} \mathrm{ha}^{-1}$ in spring and fall seasons, respectively. As seen from Tables 5 and 4 there was no 
significant difference between squash yield of the fully irrigated, $\mathrm{DI}_{3}$, and RDI techniques. It could be concluded that applying $\mathrm{DI}_{3}$ technique can save more than $20 \%$ of the applied water. The results obtained in this research agreed with those reported by Amer (2011) who showed that DI produced greater WUE more than fully irrigated treatments.

Table (5): The effects of irrigation treatments and potassium fertilization rates on WUE of squash in both spring and fall seasons.

\begin{tabular}{lllccc}
\hline \multirow{2}{*}{ Season } & Irrigation & \multicolumn{4}{c}{ K Fertilization rate, $\mathrm{kg} \mathrm{ha}^{-1}$} \\
& treatment & 150 & 200 & 250 & Mean \\
\hline \multirow{3}{*}{ Spring } & $1.0 \mathrm{ETc}$ & 0.219 & 0.267 & 0.300 & 0.262 \\
& $0.75 \mathrm{ETc}$ & 0.160 & 0.260 & 0.333 & 0.251 \\
& $0.50 \mathrm{ETc}$ & 0.247 & 0.263 & 0.367 & 0.292 \\
& $\mathrm{RDI}$ & 0.216 & 0.274 & 0.298 & 0.263 \\
& $\mathrm{DI}_{3}$ & 0.236 & 0.303 & 0.374 & 0.304 \\
& $\mathrm{DI}_{4}$ & 0.279 & 0.357 & 0.459 & 0.365 \\
\hline Mean & & 0.226 & 0.287 & 0.355 & \\
\hline \multirow{4}{*}{ Fall 2018 } & $1.0 \mathrm{ETc}$ & 0.262 & 0.313 & 0.349 & 0.308 \\
& $0.75 \mathrm{ETc}$ & 0.192 & 0.206 & 0.391 & 0.263 \\
& $0.50 \mathrm{ETc}$ & 0.290 & 0.299 & 0.341 & 0.310 \\
& $\mathrm{RDI}$ & 0.292 & 0.320 & 0.347 & 0.320 \\
& $\mathrm{DI}_{3}$ & 0.300 & 0.336 & 0.426 & 0.354 \\
Mean & $\mathrm{DI}_{4}$ & 0.291 & 0.445 & 0.481 & 0.406 \\
\hline
\end{tabular}

\section{Potassium Use Efficiency of squash (KUE)}

As detailed in Table 6, KUE was negatively affected by the amount of $\mathrm{K}_{2} \mathrm{O}_{5}$ regardless the irrigation treatment used since the greatest KUE value was recorded with the combination of $150 \mathrm{~kg} \mathrm{~K} \mathrm{~K}_{2} \mathrm{O}_{5}$ and various irrigation treatments in comparison to other two greater $\mathrm{K}$ rates. In both seasons, the highest KUE values of 5.42 and $5.40 \mathrm{~kg}$ squash seeds $(\mathrm{kg}$ $\left.\mathrm{K}_{2} \mathrm{O}_{5}\right)^{-1}$ were recorded with the treatments received $150 \mathrm{~kg} \mathrm{~K}_{2} \mathrm{O}_{5} \mathrm{ha}^{-1}$. Interestingly in both tested seasons, $\mathrm{DI}_{3}$ and $\mathrm{DI}_{4}$ produced higher $\mathrm{KUE}$ values in comparison to 0.75 and $0.5 \mathrm{ETc}$ which had the same amount of applied water. This may have been a result of smaller root size. As 
noticed from the results, RDI enhanced KUE since $\mathrm{DI}_{4}$ with $75 \% \mathrm{ETc}$ and RDI produced high KUE while saving at least $20 \%$ of irrigation water applied. The lowest average values of KUE were obtained from the combinations of $50 \%$ ETc and $250 \mathrm{~kg} \mathrm{~K}_{2} \mathrm{O}_{5}$.

Table (6): The effects of irrigation treatments and potassium fertilization rates on $\mathrm{KUE}$ ( $\mathrm{kg}$ squash seeds/ $\mathrm{kg} \mathrm{K}_{2} \mathrm{O}_{5}$ ) in spring and fall seasons of 2018.

\begin{tabular}{|c|c|c|c|c|c|}
\hline \multirow{2}{*}{ Season } & \multirow{2}{*}{$\begin{array}{l}\text { Irrigation } \\
\text { treatment }\end{array}$} & \multicolumn{3}{|c|}{ K Fertilization rate, $\mathrm{kg} \mathrm{ha}^{-1}$} & \multirow{2}{*}{ Mean } \\
\hline & & 150 & 200 & 250 & \\
\hline \multirow{6}{*}{$\begin{array}{l}\text { Spring } \\
2018\end{array}$} & $1.0 \mathrm{ETc}$ & 5.42 & 4.95 & 4.44 & 4.93 \\
\hline & $0.75 \mathrm{ETc}$ & 3.11 & 3.78 & 3.87 & 3.59 \\
\hline & $0.50 \mathrm{ETc}$ & 3.48 & 2.79 & 3.11 & 3.13 \\
\hline & RDI & 4.75 & 4.54 & 3.95 & 4.41 \\
\hline & $\mathrm{DI}_{3}$ & 4.57 & 4.40 & 4.36 & 4.44 \\
\hline & $\mathrm{DI}_{4}$ & 3.93 & 3.78 & 3.89 & 3.87 \\
\hline Mean & & 4.21 & 4.04 & 3.94 & \\
\hline \multirow{6}{*}{ Fall 2018} & $1.0 \mathrm{ETc}$ & 5.40 & 4.84 & 4.31 & 4.85 \\
\hline & $0.75 \mathrm{ETc}$ & 3.11 & 2.51 & 3.81 & 3.14 \\
\hline & $0.50 \mathrm{ETc}$ & 3.44 & 2.65 & 2.42 & 2.84 \\
\hline & RDI & 5.42 & 4.46 & 3.86 & 4.58 \\
\hline & $\mathrm{DI}_{3}$ & 4.87 & 4.09 & 4.15 & 4.37 \\
\hline & $\mathrm{DI}_{4}$ & 3.44 & 3.95 & 3.42 & 3.60 \\
\hline Mean & & 4.28 & 3.75 & 3.66 & \\
\hline
\end{tabular}

\section{CONCLUSION}

This research aimed to investigate the potential of deficit irrigation to enhance water use efficiency, yield of squash under various rates of potassium fertilization in regions suffering from shortage of fresh water resources such as Nubaria region. In calcareous soils of Nubaria region, 
the yield and yield components of squash can be optimized to maximize the final income through better management of water and energy. Full irrigation regime can produce higher yield with less water use efficiency. The results further showed that deficit irrigation can be a reliable irrigation strategy for saving irrigation water in areas suffering from water scarcity since it can save water by more $20 \%$ and resultantly help to increase cultivated area in newly reclaimed regions. Solar - powered pumping drip irrigation systems would be a promising tool for producing agricultural crops in regions with no connection to traditional energy sources.

\section{REFERENCES}

Abu-Aligah, M. (2011). Design of photovoltaic water pumping system and compare it with diesel powered pumps. Jordan J. Mech Ind. Eng., 5(3): 273-280.

Amer, K.H. (2011). Effect of irrigation method and quantity on squash yield and quality. Agric. Water Mange., 98: 1197-1206.

Anderson, K.; C. Findlay; S. Fuentes and S. Tyerman (2008). Viticulture, wine and climate change. Garnaut Climate Change Review.

Burney, J.; Woltering, L.; Burkec, M.; Naylora, R. and Pasternakb, D. (2010). Solar-powered drip irrigation enhances food security in the Sudano-Sahel. Sustain Sci., 107(5): 1848-1853.

Doorenbos, J., and Kassam. A. (1986). Yield response to water. FAO, Irrigation and Drainage paper No. 33, Rome, Italy.

FAO. (1970). Physical and Chemical Methods of Soil and Water Analysis. Soils Bull. No. 10, FAO, Rome, Italy.

Fernandes, C.N.V.; Azevedo, B.M.; Camargo, D.C.; Dias, N.C.; Reboucas Neto, M.O. and Costa, F.R.B. (2016). Potassium fertilizer applied by different methods in zucchini crop. Rev. Bras. de Engen. Agr. e Amb., 20(7): 643-648. 
Giuliani, M.M.; Nardella, E.; Gagliardi, A. and Gatta, G. (2017). Deficit irrigation and partial root-zone drying techniques in processing tomato cultivated under Mediterranean climate conditions.

Gomaa, A. H. Samak, A.A. and Elshkhaby, E.H. (2018). Study the effect of partial root zone drying irrigation on tomato crop under Egyptian condition. Misr J. Ag. Eng., 35 (3): 881-898.

Haytova, D. (2013). Influence of foliar fertilization on the nutrient uptake of zucchini squash (Cucurbita pepo L. var. giromontia), Proceeding of NUTRIHORT - Nutrient management, innovative techniques and nutrient legistation in intensive horticulture and improved water quality, September 16-18, 2013, Ghent, Belgium, pp. 370-377.

Hossain, M.A.; Hassan, M.S.; Mottalib, M.A. and Hossain, M. (2015). Feasibility of solar pump for sustainable irrigation in Bangladesh. Inter. J. Energy and Envi. Eng., 6(2): 147-155.

Hu, T.; Kang, S.; Li, F. and Zhang, J. (2009). Effects of partial root-zone irrigation on the nitrogen absorption and utilization of maize. Agric. Water Mange. 96: 208-214.

Ismail, S.M. (2002). Design and management of field irrigation system. (In Arabic), $1^{\text {st }}$ Ed., Monshaet El-Maaref, Alexandria, Egypt, pp 367.

James, L.G. (1988). Principles of farm irrigation system design. John Wiley and Sons, Inc., New York, USA.

Kang, S. and Zhang, J. (2004). Control alternate partial root zone irrigation: its physiological consequences and impact on water use efficiency. J. Exp. Bot., 55 (407): 2437-2446.

Kirda, C. (2002). Deficit irrigation scheduling absed on plant growth stages showing water stress tolerance. In: Deficit Irrigation practice. Water Reports 22, FAO, Rome, pp. 1-3. 
Marjanovic, M.; Z. Jovanovic; R. Stikic and V. Radovic (2015). The effect of partial root-zone drying on tomato fruit growth. Procedia Environment Sciences, 29: pp. 87.

Mele, A. (2019). Water use efficiency and nitrogen use efficiency in drip and deficit drip irrigated sugar beets (Beta Vulgaris). MSc. Thesis, Jordan Collage of Agricultural Sciences and Technology, California State University, Fresno.

Nangare, D.D.; Singh, Y.; Kumar, P.S. and Minhas, P.S. (2016). Growth, fruit yield and quality of tomato (Lycopersiconesculentum Mill.) as affected by deficit irrigation regulated on phonological basis. Agric. Water Manage., 17: 3-79

Naor, A. (2006). Irrigation scheduling and evaluation of tree water status in deciduous orchards. Hortic Rev., 32: 111-116.

Nardella, E.; Giuliani, M.M.; Gatta, G; De Caro, A. (2012). Yield response to deficit irrigation and partial root-zone drying in processing tomato (Lycopersicom esculentum Mill). J. Agric. Sci. Technol., 2: 209-219.

Odeh, I.; Yohanis, Y.G. and Norton, B. (2010). Economic viability of photovoltaic water pumping systems. Solar Energy, 80: 850-860.

Pereira, L. S., Oweis, T., Zairi, A. (2002). Irrigation management under water scarcity. Agric. Water Manag. 57, 175-206.

Qi, D.; Hu, T.; Song, X. and Zhang, M. (2019). Effect of nitrogen supply method on root growth and grain yield of maize under alternate partial root - zone. Irr. Sci. Rep. 9,1891(2019) doi:10.1038/s41598019-44759-2.

Romero, P.; Botia, P. and Garcia, F. (2004). Effects [of regulated deficit irrigation under subsurface drip irrigation conditions on water relations of mature almond trees. Plant Sci., 260: 155-168. 
Seckler, D. (1999). Growing population faces shrinking water supply. Environment news service http://ens.lycos.com/ens/jul99/1999L-0720-01.html

Topcu, S., Kirda, C., Dasgan, Y., Kaman, H., Cetin, M., Yazici, A., Bacon, M.A. (2007). Yield response and N-fertilizer recovery of tomato grown under deficit irrigation. Euro. J. Agron. 26, 64-70.

Vermeiren, L. and Jopling, G.A. (1984). Localized irrigation. FAO Irrigation and Drainage paper No. 36, Rome, Italy.

Wei, Z.; J. Zhang; S. Xu; P.J. Cambre and W.J. Davies (2016). Carbon isotope discrimination shows a higher water use efficiency under alternate partial root zone irrigation of field grown tomato. Agricultural Water Management, 165: 33-43.

Yactayo, W.; D.V. Ramirez; R. Gutierrez; V. Mares; A. Posadas and Quiroz (2013). Effect of partial root-zone drying irrigation timing on potato tuber yield and water use efficiency. Agricultural Water Management, 123: 65-70.

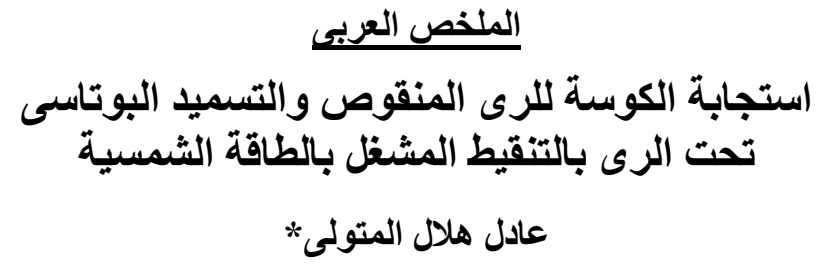

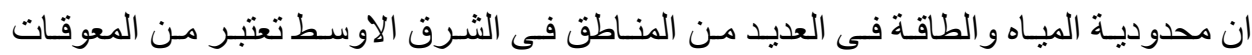

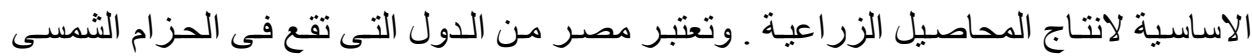

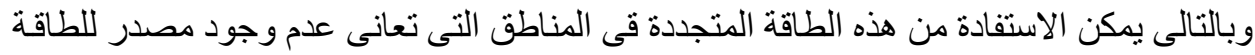

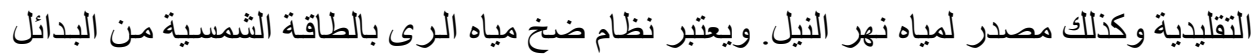

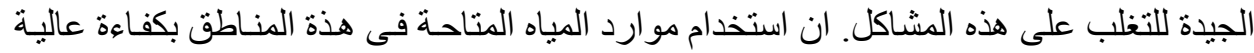

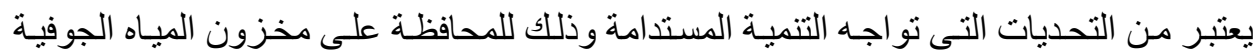

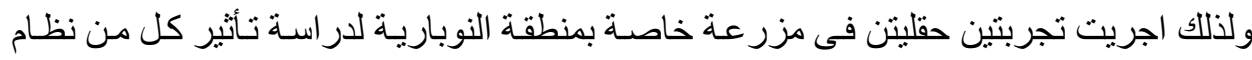

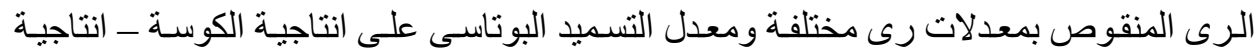

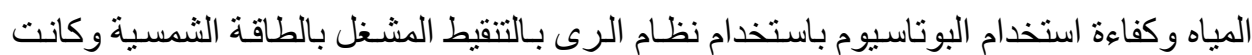

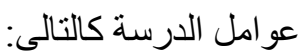

* أستاذ مساعد الهندسة الزراعية_ قسم الهندسة الزراعية_ كلية الزراعة _جامعة طنطا ــ مصر 


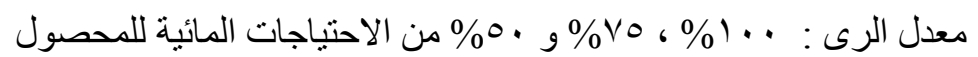

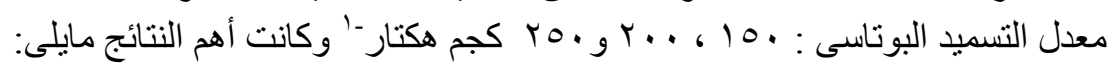

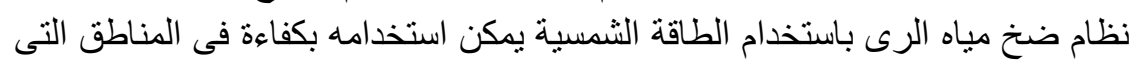

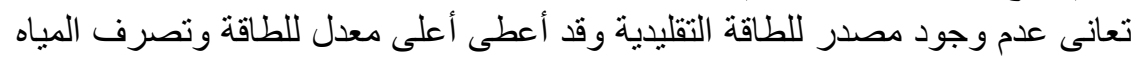

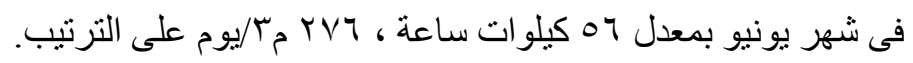

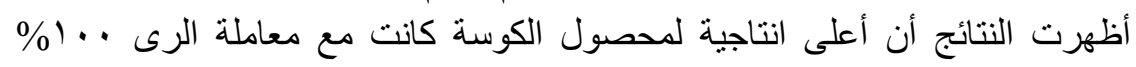

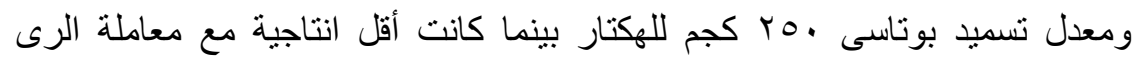

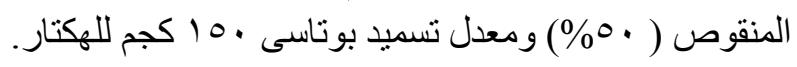

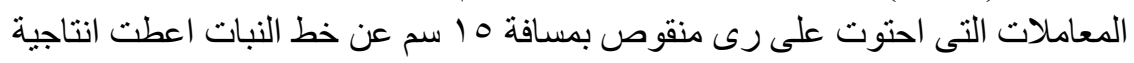

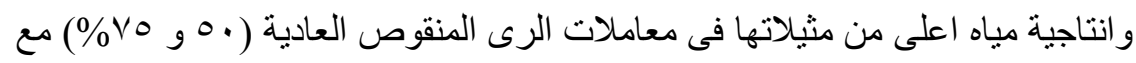
ثنبات معدل اضافة المياه.

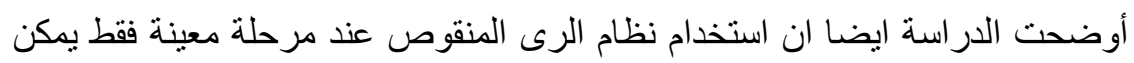

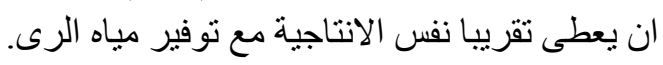

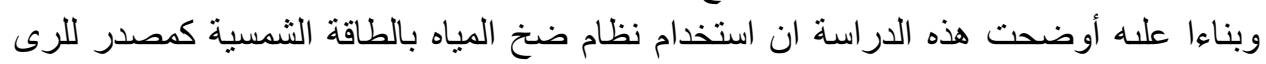

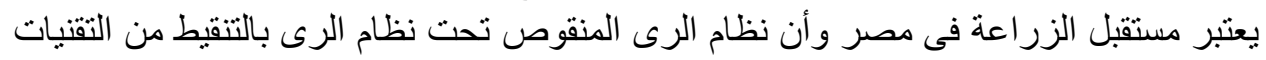

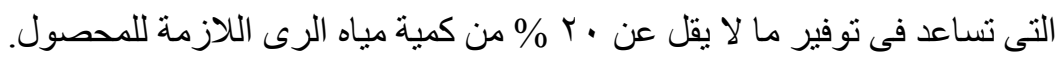

